\title{
Implementation of Indonesias foreign policy in Asean Economic Community (MEA)
}

\author{
Rosmery Sabri, Evi Yunita Kurniaty \\ Departement of Political Science, \\ Universitas Sumatera Utara, Medan, Indonesia \\ Email:faticob@gmail.com
}

\begin{abstract}
Indonesia's foreign policy in Asian Economic Society (MEA) is the embodiment of free-market principles in accordance with liberal economics thinking. The subject of implanting MEA comes to the forefront due to the government's unpreparedness through its ministry and other related institution. The readiness of businesses to take advantage of export opportunities to ASEAN market needs hard work from the government in preparing workshops as a training ground for skilled labor. Funding from banking institutions also does not seem to be a driving force for local export products. Cooperation between central, provincial, regency/municipal government still needs to be improved in order to implement foreign policies on MEA in all regions as one whole chain.This is apparent during the research into secondary data in North Sumatra Province and also in deep-diving interviews with related government officials and businesses. The proses of acquiring data are conducted in a descriptive analytics manner but the researcher preludes this by looking into profiles that have been done by North Sumatra provincial government through various media such as newspaper, online news outlet, and television which has been lacking. Information around steps and policies to be taken by the North Sumatra provincial government is not shown or described in the North Sumatra Government's website.In the future, a more concrete policy education from the central to local government is needed regarding potential business opportunity arising from the MEA cooperation. Local government is expected to be more proactive in obtaining more directions from central government. Furthermore, conducting a comparative study on MEA implementation in other provinces. On the other side, local government is also taking initiative for proactive utilization of MEA for local businesses.
\end{abstract}

Keyword: Mea, Foreign Policy, Asian

\section{INTRODUCTION}

Free trade agreement of ASEAN or better known Asian Economic Community (MEA) has come into effect at the end of 2015 precisely December 31, 2015. Some people expect MEA will have a positive impact on the Indonesian economy. However, most people consider MEA as a threat because the competitiveness of some of our industry sectors is still less competitive than other ASEAN countries.

Prior to the introduction of the MEA, due to the liberalization of existing trade, the invasion of imported goods entering Indonesia is no longer under control. From the start of electronic goods, textiles and even food affairs Indonesia have long been dependent on the imports so that from the side of the food we face an emergency import. Therefore, the implementation of MEA only further strengthens the dominance of imported goods. The enforcement of the MEA will also automatically threaten domestic industries, especially small and medium-sized industries, which are already burdened with the withdrawal of subsidies and charges.

With the implementation of the MEA, Indonesia is still predicted to be a target market due to Indonesia's weak competitiveness. Indonesia's competitiveness is still weak compared to Singapore, Malaysia, and Thailand. Moreover, Asian Economic Community (MEA) not only open the flow of trade in goods or services, but also the professional labor market such as doctors, lawyer, accountants, and others. As a result, MEA will more open opportunities for foreign workers to fill various positions and professions in Indonesia are closed or minimal foreign workers.

The key to success to maximize Mea opportunities is to improve Indonesia's competitiveness. It must be admitted that Indonesia has not become the number one in ASEAN regarding competitiveness. Based on the 2014 Global Competitiveness Index released by the World Economic Forum (WEF), Indonesia is ranked 34th out of 144 countries in the world. Still under Singapore (ranked 20th, Malaysia (ranked 20th) and Thailand (ranked 31st).The overlapping regulatory bureaucracy, the 
relatively low Human Resources, and the low quantity and quality of infrastructure are the factors contributing to Indonesia's competitiveness ranking in Asia Southeast.

To have the competitiveness and ready to compete is by way of self-improvement. Selfimprovement should be done by all parties including stakeholders and issuing policies. The resulting policy should take advantage of existing opportunities and address any challenges and obstacles that occur after the implementation of the MEA. The policy is like a massive socialization of the implementation of the MEA so that all parties can take part in the MEA. Should be both able to take advantage of opportunities and able to answer the obstacles that occur. Based on the description that has been presented, then the problem in this research is how the implementation of government policy in ASEAN economic society.

\section{METHODOLOGY}

In this study using qualitative methods. Meriam (1988) mentions the assumption of qualitative research is a study that emphasizes more attention to the process, not the result or product. The process of qualitative research is inductive in which researchers build abstractions, concepts, and theories themselves.

Qualitative researchers stand firm in an enemy position (trying to find facts "what" is "not" what they should be ".) Denot and qualitative methods of this researchers are given the autonomy as much as possible to develop the research process (Bungin, 2007: 5) Using this method is expected that the preparations and constraints faced by Indonesia in the ASEAN Economic Community can be analyzed in depth and in depth.

The research uses qualitative research methods, which theoretically qualitative research format is different from the quantitative research format. Qualitative research is an approach that is also called investigative approach because researchers usually collect data by face to face face-to-face and interact with people in place of research (McMillan \& Schumacher, 2003).

Furthermore, qualitative research according to Moleong (2007: 6) is a study that intends to understand the phenomenon of what is experienced by research subjects such as behavior, perception, motivation, action, etc., holistically, and by way of description in the form of words and language, in a specific, natural context and by utilizing various natural methods.

Qualitative research is not bound by any single discipline (Denzin and Lincoln, 2009: 4). In the context of this research is in line with research problems that combine political disciplines and the study of political economy. Qualitative methods used here trying to build the concept of free trade that comes from the idea of liberalism. Here much talked about liberalism theory to examine the implementation of the Economic Community of Asian (MEA) in North Sumatra. This is the argument that in this study paradigm and qualitative research methods become relevant.

In sharpening the analysis, this study compares the circumstances occurring in North Sumatra within the framework of MEA, with West Java Province. West Java Province which is considered ready to face MEA especially from Micro, Small and Medium Enterprises (UMKM). As is known that the empowerment of SMEs is one of the strengths of Indonesia if you want to win in the ASEAN Community economic competition.

\section{RESULT AND DISCUSSION}

In the free trade of the ASEAN Economic Community, each country will compete to gain the independence of the free trade. Each country competes in the free market, including its people who inevitably have to compete as well. In this case, the Indonesian people themselves are not really ready to face the free market. Many things that make the people of Indonesia are considered still not able to compete with other countries in Southeast Asia, such as the lack of information and socialization of the government to the main actor MEA itself which resulted in the emergence of doubts and even pessimism in the face of the MEA, unpreparedness of resources human, infrastructure owned by Indonesia also still not support and many other things that need to be prepared for Economic Community of Asian (MEA).

In addition to the things that cause Indonesia as pessimistic as expressed above, Indonesia also has many opportunities in the ASEAN Economic Community (MasnurTiurmaida Malau, 2014: 170-171): 
a. Indonesia as the world's largest petroleum market, with the largest population in Southeast Asia's $40 \%$ of the total Asian population. This makes Indonesia a productive and dynamic economic country that can lead the Asian market in the future with market and investment opportunities. Indonesia is a potential market that has a wide area and amount.

b. Indonesia becomes an investment destination country because the proportion of ASEAN countries' investment in Indonesia reaches $43 \%$.

c. Indonesia has the opportunity to become an exporting country. Indonesia has an opportunity as an exporting country, where the value of Indonesia's exports to intra-ASEAN is only $18-19 \%$ while out of ASEAN is around $80-82 \%$ of its total exports. This means an opportunity to increase the deficit against some Asian countries.

d. Trade liberalization of Asian goods. Market conditions that are already free in the region by itself will encourage the producers and other business actors to produce and distribute quality goods efficiently so as to compete with products from other countries. On the other hand, consumers also have alternatives of diverse choices that can be selected according to the needs and capabilities, from the cheapest to the most expensive.

e. Indonesia's demographic bonus as the country with the largest population number will gain its own advantages, called demographic bonus.

f. The Service Sector is open when MEA is switched. Service sectors established are tourism, health, aviation, and e-ASEAN and then will be followed by logistics.

g. Capital flows are seen from the side of foreign capital withdrawal, ASEAN as a region known as the goal of global investment.

In the face of the ASEAN Economic Community, the Indonesian government will inevitably have to take strategic steps in order not to become a marketing country for foreign products while for investment, other countries prefer to invest in countries whose business implementation has increased such as Thailand, Malaysia, Vietnam and Brunei Darussalam. For that, the government must take strategic steps that can be done, among them (Dian Wahyudin, 2014: 16-17).
The readiness of Indonesia in the implementation of the ASEAN Economic Community (MEA) is still hampered by the weaknesses of various fields, among others, the readiness of Human Resources (especially UMKM), production facilities and infrastructure, business capital, regional infrastructure, and the competitiveness of UMKM products. The enforcement of the MEA policy can be a blessing or otherwise capable of being a threat. This is very dependent on the readiness of the central and local governments and communities, especially MSMEs in the face. However, until now Indonesia still faces fundamental problems, especially in the economic, political, socio-cultural and security stability.

The Government makes a number of strategic and technical policies, both sectoral and cross-sectoral. Cross-sectoral strategic policies include the issuance of the Master Plan for the Acceleration of Economic Development of Indonesia (MP3EI), the development of the National Logistics System (Sislognas), the policy of the national industrial sector downturn, the food security policy, the Indonesian National Work Competency System, establishing ASEAN Center and ASEAN Study Center in universities and so on (Center of Public Relations Ministry of Trade Republic of Indonesia, 2015).

Broadly speaking, the strategic steps that must be taken by the government are among others by reforming potential strategic sectors and related to the mechanisms set by ASEAN in order to create a free market and international production base. Strategic steps include:

\section{A.Socialization To Stakeholders}

Local government needs to socialize to all stakeholders (Civil, Police and Military Officers, Business World, Banking, UMKM, and society at large) because until now the MEA is understood only by upper middle class. It needs to be done like a democratic party, for example with banners, umbul banners and boards at various public facilities that inform the implementation of the MEA.

Policies issued by the central government do not work because of a very poor socialization process. The technical SKPD is like a road in place 
to implement programs related to the ASEAN Economic Community.

As expressed by Mr. Ir. Sujatmiko, MSi (Head of UPT Training and Export Promotion Center of Industry and Trade Office of North Sumatera Province) in a research interview that after MEA launching in North Sumatera in 2015 there is no regulation from the central government regarding the steps that should be implemented by each region in the effort MEA. Bapedda leading sector does not also provide direction to the technical SKPD in every work program that is run. This proved to be no budget related to the ASEAN Economic Community (MEA) in 2017.

MEA is not the focus of our work program. There is no central regulation concerning MEA preparatory activities. At the time of launching MEA in DPRD 2015 ago which resulted in the inscription was agreed by the stakeholders SKPD technical, but now no programs are running. The planned program is stagnant, as regulation from the central government is not available (Interview with Sujatmiko, MSi)

\section{B.Increased Economic Competitiveness}

Competitiveness is one of the important aspect in making ASEAN as single market and production base, competitiveness is one of the pillars of MEA which aims to make ASEAN as a regional region with high competitiveness in the region and in an international environment. It is also a requirement for Indonesia and other ASEAN countries to increase their economic competitiveness in order to face the economic integration of MEA.

For the Provinces of Indonesia is a very heavy work and is the responsibility of all parties. For example, North Sumatra Province, according to Mr. Ir. Sujatmiko, MSi (Head of UPT Training and Export Promotion Center of Industry and Trade Office of North Sumatera Province) in a research interview that to improve the economic competitiveness much to be improved one of them is the quality of human resources in North Sumatra. This is the responsibility of all parties.

In North Sumatra the bureaucracy is not yet efficient, the taxation regulations are burdensome, the policies are not solid, high still
Corruption, Collusion, and Nepotism is the most basic constraint of the Province of North Sumatra. This is as expressed by DR. Ir. Munir Tanjung, MM (Secretary of Bapedda of North Sumatera Province), if the government can not fix all our internal deficiencies, we are worried that we will not compete with other countries in Asean. Not only that North Sumatra should be more active in improving themselves, in order to compete with other provinces, can be taken an example that North Sumatra far behind from West Java related to the readiness of MSME in MEA. Bappeda continues to coordinate with other institutions related to macro policy. But in the implementation of the policy still cannot be monitored by Bappeda, because in real terms in the field no policy is implemented properly.

According to Munir Tanjung, the government should be more hard work in preparation of MEA. Preparation in the MEA has already been prepared by Bappeda Labuhan Batu Selatan (Labusel). They are more synergistic in providing studies to relevant offices in the implementation of the MEA in Labusel.

This is certainly a challenge as well as a tough task for the ranks of government, both central and local to overcome them. The successful implementation of Bureaucracy Reform will greatly support the improvement of competitiveness that is sufficient in facing the MEA.

\section{C.Infrastructure Improvement}

The challenges faced by the Central Government and Local Governments in infrastructure are among others (a) repairing all damaged infrastructure, such as hollow and bumpy roadways and partially destroyed by landslides in a short time; (b) construct toll roads or railroads to ports, and the construction of ports such as Tanjung Api and others which have been the entrance to the goods in the next few years; (c) increase electrical and cleaner acceleration within the next two years, and more. Logistics is also the most important part of infrastructure in relation to economic interests or the pulse of trade in particular. Especially in the case of a regional production center, logistics, such as ports and motorways from factory to port or vice versa or from port to marketing center, is very important, Without smooth logistics, production and trade 
processes can be disrupted. Inflation will be higher due to the stagnation in highways and ports. Clearly, competitiveness is also determined by the speed of incoming and outgoing goods. Once the importance of logistics makes this sector the first to be integrated into the MEA implementation process.Reformasi Iklim Investasi

In the face of the implementation of the MEA, the Region must prepare itself by improving the investment climate through improving economic infrastructure, creating macroeconomic stability, as well as legal and policy certainty, and cutting down on the high-cost economy. One of the concrete steps that continue to be done by Indonesia with the passing of PMA Law no. 25 of 2007 on investment (replacing Law No.1 Year 1967 which has been changed to Law No.11 Year 1970). Under Law No. 25 Year2007 it can be said to have covered all important aspects (including the matter of coordination services, facilities, and rights of investors, employment, and sectors of the main concern of investors) that are closely related to efforts to increase investment from the side of entrepreneurs/investors. There are some of these aspects which have been a serious problem faced by entrepreneurs/investors. Therefore it will have a very positive effect on investment activities in the region.

ASEAN in terms of withdrawal of foreign capital flows is known as the goal of global investment. MEA opens opportunities for Indonesia to capitalize on capital inflows into the region. The capital flows not only in the form of portions of the regional portfolio but also direct capital flows (PMA). In terms of improving the capacity and quality of institutions, related regulations, and human resources, various regional cooperation programs were undertaken are inseparable from the necessity of harmonizing standardization, as well as following mutually agreed agreements. This means there will be capacity building process in various institutions, sectors, or related regulations. The implementation of ASEAN Single Window strongly supports this opportunity.

\section{Empowerment of UMKM}

Micro Small Medium Enterprises and Cooperatives (MSMEs/ UMKM) as a very strategic national economic sector in the development of people's economy, has always been a central issue contested by politicians in attracting mass sympathy. The academicians and NGOs also discussed it in seminars, but rarely did real efforts that have an impact on improving the prosperity of UMKM. As the axis of national economic revival, UMKM is not a business sector without problems. In its development, this sector is facing many problems that until now have not received serious attention to overcome them.

Information technology is a form of technology used to create, store, alter, and use information in all its forms. Through the utilization of this information technology, SMEs can enter the global market. Utilizing information technology in running a business or commonly known as ecommerce for small companies can provide flexibility in production, enabling faster delivery of subscribers to software products, delivering and receiving offers quickly and sparingly, and supporting paperless fast transactions. Utilization of the internet allows SMEs to do marketing with the aim of global markets, so export opportunities are very possible.

Provision of capital is also very important to increase the production capacity of a business. Therefore, it takes a capital institution that is easily accessible by business actors of various scales. Especially the perpetrators of SMEs are often difficult in the addition of capital.

It must be admitted that many people who do not understand with MEA, especially among SMEs. Our SMEs have been moving in the informal sector in rural areas and tend to be not well informed. The role of government in socializing the potential and opportunities of MEA still need to be pushed, especially among SMEs to be able to compete with another state SMEs.

SMEs themselves are an important part of the ASEAN economy. To date, $96 \%$ of ASEAN enterprises are SMEs comprising 50\% to $95 \%$ using domestic workforce; contributes 30\% to $53 \%$ of Gross Domestic Product (GDP), and contribute $19 \%$ to $31 \%$ of exports. While Indonesian SMEs accounted for 99.98 percent of business units in Indonesia, accounted for 57 percent of national GDP and more than 97 percent of domestic workforce absorption. 
The issue of preparedness in facing the MEA is not a bargain. Other countries are also facing the same conditions. A survey conducted by the Asian Development Bank and the Institute of Southeast Asian Studies (2015) found that less than a fifth of Asean's regional business is ready to face the ASEAN economic community.

In the middle of this year, the Malaysian Ministry of Commerce surveyed about 1,000 small and medium scale industries. More than half of those who do not know about the ASEAN Economic Community, especially what can be done for their business. There is about 60 percent of SMEs unaware of opportunities in other Asean countries, whether they are unaware of what the Asean Economic Community (MEA) is or are not aware of the opportunities available in ASEAN countries.

Similar conditions are also experienced by several other ASEAN countries. Myanmar, for example, also faces obstacles that are not much different. Even Myanmar entrepreneurs admitted that they are not ready to join the market of Asean Economic Community (MEA). This means that Indonesia is not the only ASEAN country that still needs more preparation.

MEA provides many opportunities as well as challenges for SMEs. As a free trade area, more than 70 percent of products made in ASEAN will not be charged, aka zero tariffs. This makes free movement of goods and services that are expected to reduce the price of raw materials and production costs in Asean by 10-20 percent.

While from the trade side many positive things that can be achieved ie from the side of the tariff reduction. This will make the flow of goods will be more competitive. Unfortunately, this tariff reduction has not been exploited by SMEs. According to estimates, only about 20-25 percent of Indonesian companies are taking advantage of the common effective preferential tariff (CEPT) prevailing in AFTA or MEA. As a result, this tariff reduction opportunity is widely used by multinational companies.

In facing the MEA, small and medium enterprises (SMEs) are urged to be able to integrate with the Asian free market (MEA) into an opportunity to grow. The Asian economic community provides an opportunity for SMEs to become a major player in the ASEAN market and allows for integration in regional production networks and global value chains.

The challenge is not only the responsibility of SMEs but also the government. Macroeconomic competitiveness must also be able to compete with other countries. This competitiveness is expected to encourage SME management to create the necessary business structures that can support more efficient operations and develop more flexible capabilities in competing in the intraASEAN region.

Another issue that must be faced is the internal SMEs themselves in the face of the MEA. To do so, SMEs are encouraged to have a competitive mindset, connect to the target market; in accordance with international standards and best-in-class processes or benchmarking; competing sustainably, and adapt to best business practices.

In addition, SMEs should be able to adapt to the overall business environment, ease of access to finance, access to markets, and productivity and efficiency. Access to financial institutions is a major obstacle since financing for SMEs still uses commercial credit schemes, even Indonesia's financing rates are far from competitive compared to other Asean countries.

Not to mention micro-enterprises that have the potential to grow from small or medium-sized businesses are still constrained to connect with financial institutions because they have no financial documentation and records, no banking links, and are less financially literate. Asymmetry of SME credit information, availability or lack of secured credit, incompatibility of SME financing programs, further add to the problem.

Meanwhile, banks should also be able to bridge better access to finance SMEs. This can be achieved through enhancing the financial risk management skills of the financial institutions and understanding further the sector's needs, thereby enhancing their ability to manage SME financing programs.

In addition, banks should help SMEs realize the importance of good payment behavior for themselves as it will be able to support credit 
demand for their SMEs. SMEs must also understand and control financial and liquidity risks, so as not to incur higher debt than their income, avoid identity fraud (their personal information is used by others to get credit) and so on.

Until now the North Sumatra Provincial Government, including the District / City Government, does not have a blueprint specifically addressing and preparing the ASEAN Economic Community (MEA). Various efforts and socialization in order to prepare MEA have actually been implemented in various meetings, seminars, and workshops in North Sumatra Province but until now has not been realized in a specific blueprint in the face of the MEA.

Various agencies/agencies in the Government of North Sumatra Province, in general, have a commitment and understand the various opportunities and threats with the implementation of the MEA. The commitment is realized in the proposed programs and activities in the budget of the Government and Regional Expenditure (APBD) both at the provincial and district/city levels in the framework of socialization and efforts to improve the quality of human resources and the quality of UMKM products. Other activities undertaken by the government in preparation and dissemination of the MEA are by carrying out various advocacy activities both through the Regional House of Representatives (DPRD) in relation to the proposed APBD policy involving various programs and activities in the preparation of the MEA.

Other advocacy activities are carried out through an approach with various religious leaders, community leaders and local leaders in the hope that the preparation of the MEA is supported and understood as well as a joint activity requiring cooperation and support from all parties. In addition, the Provincial / Regency / City Government in North Sumatera, in general, has tried to create and prepare good network with various non-governmental organizations (NGOs), universities and various companies to strengthen the quality of human resources, UMKM products, and SME product marketing sector in preparation of MEA.

The government of Provincial / Regency / Municipality Government in North Sumatera has priority in an effort to increase area capacity in the form of program/activity, assistance to UMKM activity through related offices and economic sector in general. The Provincial / Regency / City Government in North Sumatera has also tried to provide services to the preparation of MEA in the form of mentoring activities, the formation of working groups, Education Communication and Information (IEC) activities as well as socialization through various communication media.

North Sumatera Provincial Government has made various efforts in supporting the regional apparatus (SKPD) and business sector (UMKM) in the implementation of the MEA. Such support includes the issuance of Decree (SK) Local Government in order to support the sector of SMEs in business development so that it is expected to assist the readiness of MSMEs in the implementation of the MEA. Socialization related to the various strengths, weaknesses, opportunities, and threats in the implementation of the MEA has also been implemented in various cross-sector meetings involving SMEs in North Sumatra Province, with the hope that the community knows, understands and is ready in the implementation of the MEA, and in the meeting can be explored various policies and strategic steps that must be implemented to strengthen the various potentials of UMKM products so that it is expected to be ready and able to compete with foreign products when later has been applied MEA.

The role of North Sumatera Provincial Government in these MSME credit schemes is on the side of APBD funds for credit interest subsidy, while total credit/financing (100\%) comes from state-appointed banks as implementing banks. In addition, the government plays a role in preparing MSMEs to be financed by the scheme, establishing policies and business priorities that will receive credit, coaching and mentoring during the loan period, and facilitating the relationship between MSMEs with others.

In today's credit scheme that is very familiar in the community is the People's Business Credit (KUR), which is specifically intended for MSMEs with the category of business feasible, but does not have enough collateral in the framework of banking requirements. KUR is Credit or financing to MSME and Cooperative who are not 
receiving Creditor Financing from Banking and/or who are not receiving Credit

Program from Government at the time of application for Credit / Financing is submitted. The final goal of the KUR Program is to boost the economy, poverty alleviation and employment. KUR is a credit provided by banks to MSMEs in the form of working capital and investment for productive enterprises that feasible but not yet bankable. The aim is to accelerate the development of the real sector (especially agriculture, forestry, marine and fishery, and industry). Bank Indonesia (BI) noted that micro and small and medium enterprise (MSME) credit distribution is still very low below $10 \%$ from January to May 2011. The central bank continues to direct banks to boost the productive sector credit to prevent the overheating economy. BI distinguishes MSMEs and MKM loans because banks are currently classified as a lot of MSM credit that still smells consumptive when compared to SMEs that are productive. UMKM is purely used for business, unlike the consumer's $\mathrm{MKM}, \mathrm{BI}$ is now encouraging banks to further channel to MSMEs.

The problem of lack of capital, the bureaucracy that is very troublesome and ignorance of export procedures are perceived as an obstacle to the development of the business. This is also experienced by Rendang Yugo's business. In a research interview, the business that $\mathrm{Bu}$ Yugo pioneered has been running from 2009 and is very advanced. Several times his efforts covered by print and television media. Having complete documents but difficult for Mrs. Yugo to export formally. To fulfill orders from Malaysia and Singapore is done through an agent. Rendang Yugo already has regular customers in Malaysia and Singapore, even rendang Yugo has earned the world's best degrees of CNN. But the obstacles in exports are still felt difficult by Mrs. Yugo.

Another case with the business of Fortune Shoes in Bandung. Fortune shoe business has been able to export to countries in Europe. Even according to the southeast Asian market is not their main market. Their export business is greatly assisted by the Department of Trade and Industry of West Java Province, which always provides information and assistance to entrepreneurs in exploiting the export potential of their products. Every policy change is immediately socialized to business actors so that business actors in West Java are motivated to export goods.

In the Province of West Java, the government is very supportive of MSMEs. With the given capital disbursed by Bank Jabar Banten (BJB). As expressed by Dra. Hj. Elis Yatimah, MM (Head of Institutional Cooperative Office of Cooperatives and Small Enterprises) program of West Java Governor Ahmad Heryawan who strongly supports the development of the creative economy through SMEs in West Java. The work program is very successful and proven West Java Province is a benchmark of the creative economy in Indonesia.

With the phrase "West Java Kahiji in Asian" Department of Cooperatives and Small Enterprises of West Java Province take measures to build human resources and cooperatives SMEs are competitive, build productivity of cooperatives and SMEs West Java, floating Cooperatives and Enterprises of SMEs West Java, increase entrepreneurial participation in economy of West Java, and build a strong West Java entrepreneurship.

\section{E. Improving the Quality of Human Resources (HR)}

HR is a very important thing as a perpetrator in the MEA. HR government apparatus and business world of quality will be able to compete and a strong challenge. Skillful, disciplined and innovative in taking ideas, steps, and actions. Increasing the quality of human resources for example with language training, skills development can be done with training, workshops, regular meetings between economic actors, as well as networking development.

The competitiveness of Indonesia's human resources should be improved both formally and informally. At least meet the requirements of the MRA (Mutual Recognition Arrangement) approved by the ASEAN Member States. The quality of Indonesian labor must be increased so that it can be used both domestically and intra-ASEAN, to prevent the flood of skilled labor from abroad. Work is not easy of course. Because it requires a blueprint of the education system as a whole and certification of various related professions. 
The Ministry of Manpower made three pillars of efforts undertaken to confront MEA. First, the acceleration of the implementation of the Indonesian National Qualification Framework (KKNI). Second, the Competency Based Training (PBK) is conducted. Third, Competency certification.

Improving the quality of human resources is clearly a key element in meeting the opportunities of MEA. Human resources, skilled and innovative in taking ideas, steps, and actions, is the basic capital that must be improved in addition to foreign language mastery. Skill development can also be done with training, seminars and workshops both nationally and internationally, regular meetings among economic actors, as well as networking development so that business actors always follow the latest developments in the economy

\section{F.Increased Participation of All-State Elements}

Increased understanding will allow the preparation process not only to be carried out by the relevant authorities but also with all stakeholders. Negative effects of integration that may occur in the short term should be clearly communicated to the affected sectors to assist their preparation through retraining, skills upgrading, and other slow transition shifts. The existence of intensive consultation with affected groups can avoid unwanted reactions.

\section{CONCLUSION}

The free trade as meant in the first pillar of AEC Blueprint is to make ASEAN economic region a single market and production base. The achievements to be gained are markets with free flow of goods, free flow of services, free flow of investment, free flow of skilled and educated personnel, as well as a more free flow of capital in the ASEAN region.

For Indonesia, the establishment of MEA 2015 will present some challenges that are not only internal in the country but moreover the competition with other ASEAN countries and other countries outside ASEAN such as China and India. This intense competition will have an impact on competitive price, not only commodities/products/services of major industry (UB) but also UMKM sector due to the similarity of product characteristics. The ASEAN Leaders have agreed to establish the ASEAN Community 2015 with its 3 pillars: ASEAN Political-Security Community (APSC), ASEAN Economic Community (AEC) and ASEAN Socio-Cultural Community. For that matter have been prepared Blueprint for each Pillar. In that context, the ASEAN Economic Community, is the realization of the ultimate goal of economic integration in accordance with the vision of ASEAN 2020, which is based on the mutual interests of ASEAN member countries to deepen and expand economic integration through existing initiatives and new initiatives with a clear time frame with the principles : open economy, outward-looking, inclusive, and market-oriented, in accordance with multilateral rules and abiding by the rule-based system so that the fulfillment and implementation of economic commitments can be effective. ASEAN as a single market and production base has 5 free flow elements namely: the free flow of goods, free flow of services, free flow of investment, free flow of capital and the free flow of skilled labor.

In facing the MEA of North Sumatra Province, it is necessary to increase the identity and extension of socialization and assistance to business actors, especially MSMEs in the aspects of capital, production and operation, financial management, marketing network and partnership network, so that all business actors are fully prepared to face the MEA.

The Government of North Sumatra should make many improvements and improvements as soon as possible in order to compete in the global competition. For the first phase of the implementation of the North, Sumatra MEA lags behind other provinces of West Java. With the potential that exists in Indonesia, Indonesia is actually very capable of competing in the Asian free trade. Indonesia, which has the largest population in Southeast Asia is a very potential market utilized. If we can win the competition in the domestic market alone is the main strength, that is the effort to empower SMEs. MSMEs that produce a distinctive and good product should be able to win the competition in the domestic market, Southeast Asian market and world market. 


\section{ACKNOWLEDGMENT}

Thank you, authors, say to the Research Institute of USU (LP USU) who has facilitated in progress and funding in this research. This paper is the result of research conducted in the Talents program held by the USU Research Institute.

\section{REFERENCES}

Association of Southeast ASEAN Nations. 'ASEAN Economic Community Blueprint', Jakarta: ASEAN Secretariat.

Budi Winarno. (2011), Contemporary Global Issues. Jakarta: PT. Exciting Books.

Luhulima, C.P.F. (2010), 'Southeast Asia Dynamics Towards 2015', Jakarta: Pustaka Pelajar cooperates with Center for Political Research (P2P) LIPI.

Center for Public Relations Ministry of Trade Republic of Indonesia. 2015. Welcoming the ASEAN Economic Community 2015. Jakarta. Ministry of Trade of the Republic of Indonesia.

Berry A. E. Rodriguez and Sandae H. (2001), 'Small and Medium Enterprise Dynamic in Indonesian', Bulletin of Indonesian Economic Studies, Vo.37, No. 2, p. 19.

Malau, Masnur T. (2014) 'Legal Aspect of Indonesian Government Regulation Against Regional Economic Liberalization: ASEAN
Economic Community 2015', Journal Rechts Vinding, Vol 3 No 2, p. 163-181.

Mitsuro, H, (2002) 'Development of SMEs in the Indonesian Economy', Journal of Asian Economics, p. 9.

Sarman, Ma'mun. (2016), Report on the Assessment of Expert Staffs of Ministry Experts in the Implementation of MEA-Mainly Network Mechanisms and Assistance for Housing IndustryCase Study in the Province of North Sumatra and East Java, Jakarta. Ministry of Women Empowerment and Child Protection of the Republic of Indonesia and Institute for Research and Community Service (LPPM) IPB.

Sudana, Raisa Samantha. (2014), 'The Role of Government of Indonesia's Policy in Preparing for the ASEAN Economic Community', e-journal in http://www.conftool.com/sudana, accessed March $14,2017$.

Suryohadiprojo, S. (2014), 'Raising the Fire of Pancasila', Jakarta: Kompas Publisher.

Wahyudin, Dian. (2014) 'Opportunity or Challenge of Indonesia to Asean Economic Community (AEC) 2015, Prociding. 